\title{
Environmental literacy of pupils and its investigation in the Czech Republic
}

\author{
Silvie Svobodová
}

\section{Contact}

Charles University

Faculty of Education

Magdalény Rettigové 4

11639 Prague 1

Correspondence:

silvie.svobodova@pedf.cuni.cz

Copyright $@ 2020$ by the author and publisher, TBU in Zlín.

This work is licensed under the Creative Commons Attribution International License (CC BY).

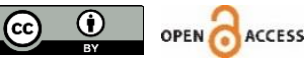

Abstract: Environmental literacy is a concept consisting of knowledge, attitudes, sensitivity and behaviour. In this text we present a pilot study of a research tool focused on measuring the environmental literacy of ISCED 2 pupils. Through the study we measured the relationship between environmental literacy and selected variables (gender, grade and leisure activities). The target group consisted of pupils in the 6th to 9th grades of lower secondary schools, and the total number of respondents was 467. The inner consistency (Cronbach's $\alpha$ ) of all tool scales (knowledge, attitudes, sensitivity, behaviour) reached acceptable values in the range of .71-.79. Spearman's correlation showed a statistically significant relationship mainly among the scales of attitudes, sensitivity and behaviour. Significant correlation coefficient values ranged from $<.44$ to $.65>$. Significant differences appeared between boys and girls in regard to attitudes, sensitivity and behaviour scales, where girls reached higher scores. Girls showed more pro-environmental attitudes, sensitivity and behaviour than boys. It was also found that the pupils' environmental knowledge increases with age. However, this does not apply to the scales of attitudes, sensitivity and behaviour. There was a high correlation between environmental literacy (excluding knowledge) and the leisure activities of pupils (outdoor activities, ICT, hobbies and sport). Leisure activities in combination with age can be considered essential determinants of environmental literacy, e.g. they predict $33 \%$ of the variability in the sensitivity scale.

Keywords: environmental literacy, pupils, ISCED 2, Czech Republic

\section{Environmentální gramotnost žáků a možnost jejího zjištování v ČR}

Abstrakt: Environmentální gramotnost představuje koncept zahrnující environmentální znalosti, postoje, senzitivitu a jednání. $V$ rámci pilotního testování autorského výzkumného nástroje zaměřeného na měření environmentální gramotnosti žáků 2. stupně ZŠ byla zjištována také souvislost environmentální gramotnosti a proměnných (pohlaví, ročník a volnočasová aktivita). Studie byla realizována v České republice za účelem ověrení aplikovatelnosti nástroje $v$ českém prostředí a jeho následného použití $v$ rámci většího výzkumu na rozšířeném vzorku. Cílovou skupinu tvořili žáci 6 . až 9 . tříd ZŠ a odpovídajících 
ročníků víceletého gymnázia. Celkový počet respondentů činil 467. Vnitřní konzistence (koeficient Cronbachova $\alpha$ ) všech škál nástroje (znalosti, postoje, senzitivita a jednání) dosahovala prijiatelných hodnot $v$ rozpětí $0,71-0,79$. Spearmanovy korelace prokázaly statisticky významný vztah zejména mezi postoji, senzitivitou a jednáním navzájem. Signifikantní hodnoty korelačního koeficientu se pohybují v intervalu $\langle 0,44 ; 0,65\rangle$. Ukázaly se významné rozdíly $v$ postojích, senzitivitě $i$ jednání mezi chlapci a dívkami. Dívky dosahovaly vyšších hodnot, vykazovaly proenvironmentálnější postoje, senzitivitu a jednání oproti chlapcům. S přibývajícím ročníkem narůstají environmentální znalosti žáků. Pro postoje, senzitivitu a jednání to však neplatí. Prokázala se vysoká souvislost mezi environmentální gramotností vyjma znalostí a volnočasovými aktivitami žáků (pobyt v př́rodě, u ICT, zájmová aktivita a sport). Volnočasové aktivity $v$ kombinaci $s$ ročníkem Ize považovat za zásadní determinanty environmentální gramotnosti, např. variabilitu proměnné senzitivita predikují z $33 \%$.

Klíčová slova: environmentální gramotnost, žáci, ISCED 2, Česká republika

\section{Introduction}

Environmental literacy is based mainly on the principles of environmental education (Wilke, 1995) and thus represents its fundamental goal (Roth, 1992). The definition of this construct has been modified several times since the 1960s, when the concept was first introduced to the general public (McBride, Brewer, Berkowitz, \& Borrrie, 2013). Interestingly, experts' approaches to the concept of environmental literacy vary and their definitions also differ in some respects. An example of this is that Ballard and Pandya based their concept on knowledge (1990), whereas Lozzi, Laveaut and Marcinkowski (1990) and Marcinkowski (1991) added to knowledge several other important areas, such as skills, sensitivity, attitudes, values, responsible environmental behaviour and persuasion about one's own influence, including the realisation of personal responsibility.

The original concept of environmental education as a tool for shaping the necessary behavioural patterns, suitable for achieving environmental consciousness, knowledge, stance and skills, consisted in promoting common nature conservation goals (UNESCO, 1977). This concept, which represented the mainstream, was later reworded several times, and the target levels of environmental education were also defined (Hungerford, Peyton, \& Wilke, 1980; Marcinkowski, 2005). The specific definition of the field in the USA came about through discussions between international institutions, academic communities and non-governmental organizations in the social, cultural and political context of individual regions, i.e. quite unevenly (Disinger, 2005).

The structure of environmental education was subject to verification by the professional community, on the basis of which other key variables were identified. One of these was the concept of REB (Responsible Environmental Behaviour), a model of environmentally responsible behaviour which favours the development of environmental sensitivity and skills for analysing and engaging in environmental issues, including beliefs about one's own impact (Hungerford \& Volk, 1990). This was followed by the concept of environmental education based on the instrumental approach in the 1990s. The key objective of environmental education is to encourage pro-environmental behaviour as a necessary disposition for dealing effectively with environmental problems. 
An important outcome of the above approach can be seen in the guidelines of the North American Association for Environmental Education (NAAEE), which were based on a consensus among environmental education experts along with the research that was conducted. Not only do they represent the elaborated goals of environmental education, but they also recommend specific ways to implement them into the education process (NAAEE, 2010). The guidelines arose mainly as a critique of environmental education from the early 1990s, which often had a manipulative character, and also in an effort to extend its definition from mere "ecological knowledge" to affective and conative areas (Sanera, 1998).

In the Czech environment, the development of environmental education was politically conditioned and was implemented primarily within the framework of non-formal education, while theoretical reflection on it happened only minimally. In the 1950s and 1970s, it is possible to identify some basics of environmental education in nature conservation education and, later on, in education on the protection and formation of the environment. In the 1980s, this was replaced by environmental education aimed at the systematic integration into the educational system of issues connected to nature protection in a broader context. In the 1990s, the theory of environmental education did not exist in the Czech Republic, so there was not enough potential to reflect this concept further in academia. The key role in the field of environmental education has been taken on by ecological education centres, which emphasize primarily the natural science dimension, knowledge of nature, understanding of environmental connections and acquisition of desirable behaviour patterns (Činčera, 2007).

The qualitative shift and changes in the official conception of environmental education in the Czech Republic since the middle of the first decade of the 21st century, the current conception of which corresponds to generally accepted international approaches to the field, is evidence of a paradigmatic shift over the last few years. The current state of affairs in the Czech Republic can be regarded as relatively good, primarily due to the firm anchoring of environmental education in formal and nonformal education, including within relevant documents (Činčera \& Johnson, 2013).

In the official curriculum of the Czech Republic, environmental education takes the form of a crosscurricular theme specifically integrated into the relevant educational areas in connection with the School Educational Programme, which is based on the Framework Educational Programme (MŠMT, 2017). However, its conception within the Framework Educational Programme (FEP) has been criticized by both professionals (Činčera, 2009) and the educational community, leading to a modification of its concept and a reformulation of the Recommended Expected Outcomes (DOV) for environmental education (Činčera, 2011). This has largely completed the paradigmatic transformation of the concept of environmental education in the Czech Republic (Činčera, 2013), which is largely inspired by the NAAEE guidelines and should be reflected in the planned revision of the Framework Educational Programme (Činčera, 2017).

A certain revival of environmental education in the 1990s led to an increased interest in the concept of environmental literacy. Roth (1992) treats it as a possible evaluation tool for environmental education. Its definition, widely accepted by experts, conceives environmental literacy as multidimensional and made up of three levels (nominal, functional and operational) and four threads (knowledge, attitudes, skills and behaviour). Nominal environmental literacy represents the ability of an individual to understand basic concepts in the context of the environment; functional represents an understanding of the relationship between people and their environment; and, within the operational level, a person is able to adopt his/her own opinion on environmental problems and suggest effective solutions. Similarly, experts have identified and summarized the multidimensional concept of environmental literacy into four dimensions (cognitive; affective; belief in one's own influence and personal responsibility; personal and group engagement in environmentally responsible behaviour) (Hungerford et al., 1994). 
The current concept of environmental literacy is based on the documents of the North American Association for Environmental Education (NAAEE), where it is defined as a central objective of environmental education, comprehensively covering its overall objectives (NAAEE, 2010). The definition is the result of environmental education experts having sought consensus for many years (Hollweg et al., 2011). It is divided into several areas (environmental knowledge, sensitivity, attitudes towards and interest in the environment, acceptance of personal responsibility, beliefs about one's own influence, motivation including intention to act, related competences and environmentally responsible behaviour) (Daniš, 2013). It reflects the relatively broad multidimensional delineation accepted by experts, which can be summarized as having three main dimensions: cognitive, affective and conative. The basic structure of this concept of environmental literacy, which emphasizes primarily skills, along with the development of pupils' competences for the evaluation of environmental conflicts, is more or less identical to its current definition in the updated NAAEE guidelines (NAAEE, 2019). Environmental literacy is divided into the skills of interviewing, analyzing and interpreting data and information about the outside world, understanding environmental processes and systems, and understanding and dealing with environmental problems, as well as having personal and civic responsibility.

However, there are some differences between the definition of environmental literacy according to NAAEE (2010) and the characteristics of environmental education in the Czech educational documents Framework Educational Programme (Education Ministry, 2017) and Recommended Expected Outcomes (Broukalová et al., 2012). Whereas in the NAAEE documents, the term environmental literacy appears explicitly and is perceived as a fundamental goal of environmental education, the Czech concept of environmental education does not work with this term but rather defines its core goal as the development of competences necessary for environmentally responsible behaviour. Differences are also evident in the division into specific sub-areas (Daniš, 2013).

On a global scale, however, we encounter comprehensive environmental literacy studies only rarely (McBeth \& Volk, 2010; McBeth, Hungerford, Marcinkowski, Volk, \& Cifranick, 2011; Nastoulas, Marini, \& Skanavis, 2017). This could be due to the small number of suitable diagnostic tools. On the other hand, there are a number of standardized tools for testing the affective dimension, which is given the greatest attention (e.g. Bogner, Johnson, Buxner, \& Felix, 2015; Grúňová, Sané, Čincera, Kroufek, \& Hejcmanová, 2018). Recently, there has also been an attempt to focus studies more often on environmentally responsible behaviour (e.g. Erdogan, Akbunar, Asik, Kaplan, \& Kayir, 2012; Osbaldiston \& Schott, 2012; Kormos \& Gifford, 2014; Svobodová, 2017).

Pupils in lower secondary education, i.e. ISCED level 2 (in the Czech Republic this corresponds to grades 6-9), form the target group of a lot of international and Czech research. Most studies focus on only one of the dimensions or a combination of two (e.g. Andrews, Tressler, \& Mintzes, 2008; Bragg, Wood, Barton, \& Pretty, 2013; Gul \& Yesilyurt, 2011; Schovajsová, 2010; Svobodová, 2017; Svobodová, 2018a; Vacínová \& Matějček, 2013).

In the USA, as part of a national survey on environmental literacy (The National Environmental Literacy Project), a Middle School Environmental Literacy Survey (MSELS) analytical tool was developed to test a wide range of environmental literacy components on a large sample of respondents (McBeth \& Volk, 2010). It is a research tool that encompasses all three dimensions of environmental literacy and is suitable for students at ISCED level 2 and 3, i.e. lower-secondary-school pupils. It consists of several subscales which determine, in addition to demographic variables (I. About Yourself), ecological knowledge (II. Ecological Foundations), attitudes (III. How You Think About the Environment), commitment to pro-environmental behaviour and declared behaviour (IV. What You Do About the Environment), environmental sensitivity (V. You and Environmental Sensitivity, VI. How You Feel About the Environment), and the skills needed to identify, analyze, and effectively address environmental issues (VII. Issue Identification, Issue Analysis and Action Planning) (McBeth, Hungerford, Marcinkowski, Volk, \& Meyers, 2008). The tool has been deployed several times and successfully standardized mainly in the American environment (McBeth \& Volk, 2010; McBeth et al., 2011; 
Stevenson, Peterson, Bondell, Mertig, \& Moore, 2013; Stevenson, Carrier, \& Peterson, 2014), but also in Greece (Nastoulas et al., 2017). In the Czech Republic, this tool has not yet been used in its entirety. Only some subscales have been used, e.g. the scale for determining environmental or ecological knowledge (Činčera, 2013; Schovajsová, 2010).

One of the most well-known instruments aimed principally at the affective dimension is 2-MEV (2 Major Environmental Values), a two-dimensional scale that represents a two-factor model of one's values and attitudes towards the environment. The biocentric factor Protection analyzes the degree of motivation and willingness of an individual to behave in an environmentally responsible manner. The anthropocentric factor Utilization identifies an individual's attitudes towards the environment for the purpose of meeting human needs (Johnson \& Manoli, 2008; 2011). The applicability of the tool was verified mainly within the framework of several years of research on a sample of 10,676 respondents (Bogner et al., 2015). It is also often applied as an evaluation tool for environmental education programmes (e.g. Činčera \& Johnson, 2013; Liefländer \& Bogner, 2014). In the Czech environment, for example, Kroufek, Janovec, and Chytrý (2015) and Svobodová (2017) used the tool for different age groups.

Both the above-mentioned research tools were verified by the author of the paper in the Czech environment (Svobodová \& Kroufek, 2018; Svobodová, 2018b). Based on the analysis of psychometric parameters, the validity and reliability of these tools, either their subscales, knowledge and sensitivity (MSELS) or, in the case of 2-MEV, a whole scale (attitudes), was included in the author's toolkit for comprehensive assessment of the environmental literacy of lower-secondary-school pupils in the Czech Republic.

The paper introduces the results of the pilot testing of the tool, especially the findings on the relationships between gender, age, leisure activities and the individual dimensions of environmental literacy. The following research questions were formulated:

RQ1: What is the reliability of the subscales of the research tool?

RQ2: What are the correlations between the subscales of the research tool?

RQ3: How strong is the relationship between the variables (gender, age, leisure activities) and environmental literacy (knowledge, attitudes, sensitivity, behaviour)?

\section{Methodology}

Three lower secondary schools (two of them in medium-sized towns, one in a rural area) and a multiyear grammar school took part in the study. They were schools from the Ústí nad Labem Region that showed an interest in participating in the testing. The data were collected in autumn 2018. The questionnaires were distributed in paper form to individual schools, either in-person or through an informed contact person, and a school educator was familiarised with the procedures, requirements and objectives of the research. The respondents, of which 239 were girls and 228 were boys, were pupils in the 6th to 9th grades of lower secondary schools $(N=467)$. The proportion of respondents from individual school grades, which does not differ significantly, is presented in Table 1.

Table 1

Overview of school grades involved

\begin{tabular}{ll}
\hline Grade & Percentage from the grade \\
\hline 6. grade & $27 \%$ \\
7. grade & $21 \%$ \\
8. grade & $27 \%$ \\
9. grade & $25 \%$ \\
\hline
\end{tabular}


The Ústí nad Labem Region is the region with the lowest educational level in the Czech Republic, and a high proportion of the population do not complete secondary education (KÚ Ústeckého kraje, 2011). Pupils in the 5th and 9th grades of primary and lower secondary schools in the region achieved the second weakest result in scientific literacy in PISA 2015 in comparison with other regions (Blažek \& Príhodová, 2016). They also showed a similarly low level of knowledge compared to their peers (Čšl, 2017).

It can therefore be assumed that the results for pupils included in the research may be lower precisely because of their lower socio-cultural family background compared to a representative sample in the whole Czech Republic. The findings thus cannot be clearly generalized to the whole population of ISCED 2 pupils in the Czech Republic.

The authorial research tool, the quantitative questionnaire, is based on the MSELS and 2-MEV standard international instruments verified by the author (Appendix 1). It consists of five parts. The first part asks about the pupils' age, year, gender and leisure activities. The second part, the Environmental Knowledge scale (Part B), is a knowledge-based test, a modified version of MSELS (16 items). Basically, it is a test of "ecological knowledge", in which understanding of ecological concepts is investigated. The third part, focused on Environmental Attitudes (Part C), consists of a two-dimensional 2-MEV tool (16 items). The scale continued to be treated as one-dimensional; the individual Protection and Usage factors were not evaluated separately, and reverse scoring was also used. The fourth part, the Environmental Sensitivity scale (Part D), was taken from MSELS (9 items). The scale mainly focuses on feelings that respondents experience towards nature, motivation and expressions of interest in spending time in the natural environment. The fifth part, the scale focused on Environmental Negotiations (part E), consists of 9 authorial items.

The knowledge-based test (Environmental Knowledge Scale) corresponds in its content to the obligatory Czech curriculum and respects the current curricular documents. It is consistent not only with the themes of the educational area People and Nature and the field of study Natural Science (Fundamentals of Ecology), but also with the cross-curricular theme Environmental Education (Basic Conditions for Life) (MŠMT, 2017) and, furthermore, with the topics in Recommended Expected Outcomes for Environmental Education (e.g. Natural Connections) (Broukalová et al., 2012).

For the Environmental Knowledge scale, respondents always chose 1 correct answer out of 4 options. For the remaining scales, they expressed the level of agreement with an assertion on the five-stage Likert scale. Their responses were scored from 5 (positive) to 1 (negative). Some items were formulated in a reverse way for analysis.

The obtained data were processed by standard statistical methods using Statistica 12 software (Statsoft, 2018). Due to the relatively large sample of respondents $(N=467)$, mainly parametric methods were used. The reliability of the subscales was determined by calculating the Cronbach $\alpha$ internal consistency coefficient. More detailed results regarding the validity and other psychometric indicators of the instrument were published separately at the 13th Annual International Technology, Education and Development Conference (INTED2019) (Svobodová \& Chvál, 2019). Correlation analysis was used to identify the relationship between environmental literacy dimensions. Gender correlation was determined using a two-sample t-test, dependence on age and leisure activities through correlation analysis and, in the case of knowledge, using one-dimensional variance analysis (ANOVA); outcomes between ages were compared, where knowledge represented a dependent variable (6th, 7th, 8th and 9th grades). Multiple linear regressions were also applied to leisure activities. The analyses included knowledge, attitudes, sensitivity and behaviour as dependent variables, with leisure activities, or gender and age as independent variables (AERA, APA \& NCME, 2014). 


\section{Results}

The internal consistency of the tool was tested for reliability by calculating Cronbach's $\alpha$ coefficient, which was acceptable in all cases (Tavakol \& Denick, 2011). Table 2 gives an overview of the reliability of the tool's subscales, including the original tool values on which the individual scales are based. Environmental knowledge and sensitivity were taken from MSELS (McBeth et al., 2008), and environmental attitudes from 2-MEV (Johnson \& Manoli, 2008; 2011). Environmental behaviour is an authorial scale for which internal consistency has not yet been established.

Table 2

Reliability overview of tool scales including original values

\begin{tabular}{lll}
\hline Variable & Reliability & Original reliability \\
Cronbach's $\alpha$ & .79 \\
\hline Knowledge & .71 & .83 \\
Attitudes & .78 & .76 \\
Sensitivity & .79 & - \\
Behaviour & .79 & \\
\hline
\end{tabular}

The correlation analysis showed a relatively close relationship between attitudes, sensitivity and behaviour. The scales correlate positively with each other, with the correlation coefficient reaching higher values. Contrary to this, for environmental knowledge, a more significant relationship was observed only with attitudes. Table 3 shows the results of the correlation analysis.

Table 3

Overview of Spearman's correlations between the scales of the tools

\begin{tabular}{lllll}
\hline Variable & Knowledge & Attitudes & Sensitivity & Behaviour \\
\hline Knowledge & & .30 & .01 & .11 \\
Attitudes & .30 & & .44 & .65 \\
Sensitivity & .01 & .44 & & .63 \\
Behaviour & .11 & .65 & .63 & \\
\hline
\end{tabular}

Note: Values in bold are significant $(p<.01)$.

\section{Characteristics of variables}

For the knowledge scale, correctly answered items were scored with a value of 1 , whereas on other scales, where respondents chose responses on a five-stage Likert scale, they were scored from 5 points (positive) to 1 point (negative). In Table 4, descriptive characteristics of each variable are presented.

Table 4

Descriptive statistics of variables

\begin{tabular}{lllllll}
\hline Variable & $\mathrm{N}$ & $\mathrm{M}$ & $\mathrm{SD}$ & min. & median & max. \\
\hline Knowledge (16 items) & 467 & 10.48 & 3.12 & 2.00 & 11.00 & 16.00 \\
Attitudes (16 items) & 467 & 3.57 & .62 & 1.44 & 3.63 & 5.00 \\
Sensitivity (9 items) & 467 & 2.87 & .72 & 1.00 & 2.78 & 4.89 \\
Behaviour (9 items) & 467 & 3.44 & .74 & 1.00 & 3.44 & 5.00 \\
\hline
\end{tabular}

\section{Relationship of environmental literacy to gender}

Gender was shown to be a statistically significant variable in relation to attitudes $(p<.001)$, sensitivity $(p=.003)$ and behaviour $(p<.001)$. In all three components of environmental literacy, girls achieved higher values. Compared to boys, they had more pro-environmental attitudes, sensitivity and behaviour. The results of the two-sample t-test for attitudes and behaviour are shown in Figure 1, 2 . 


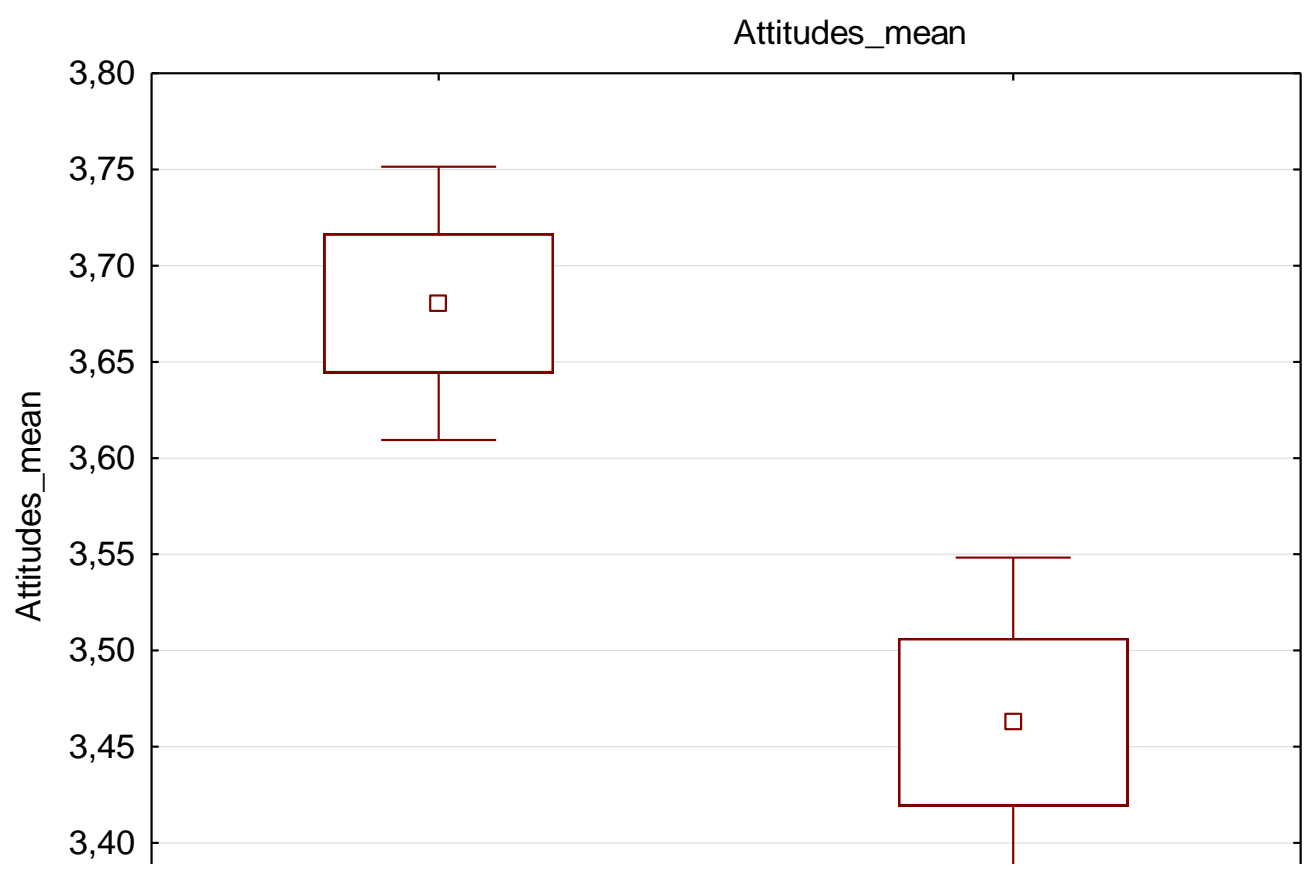

Figure 1 Relationship between declared environmental attitudes and gender

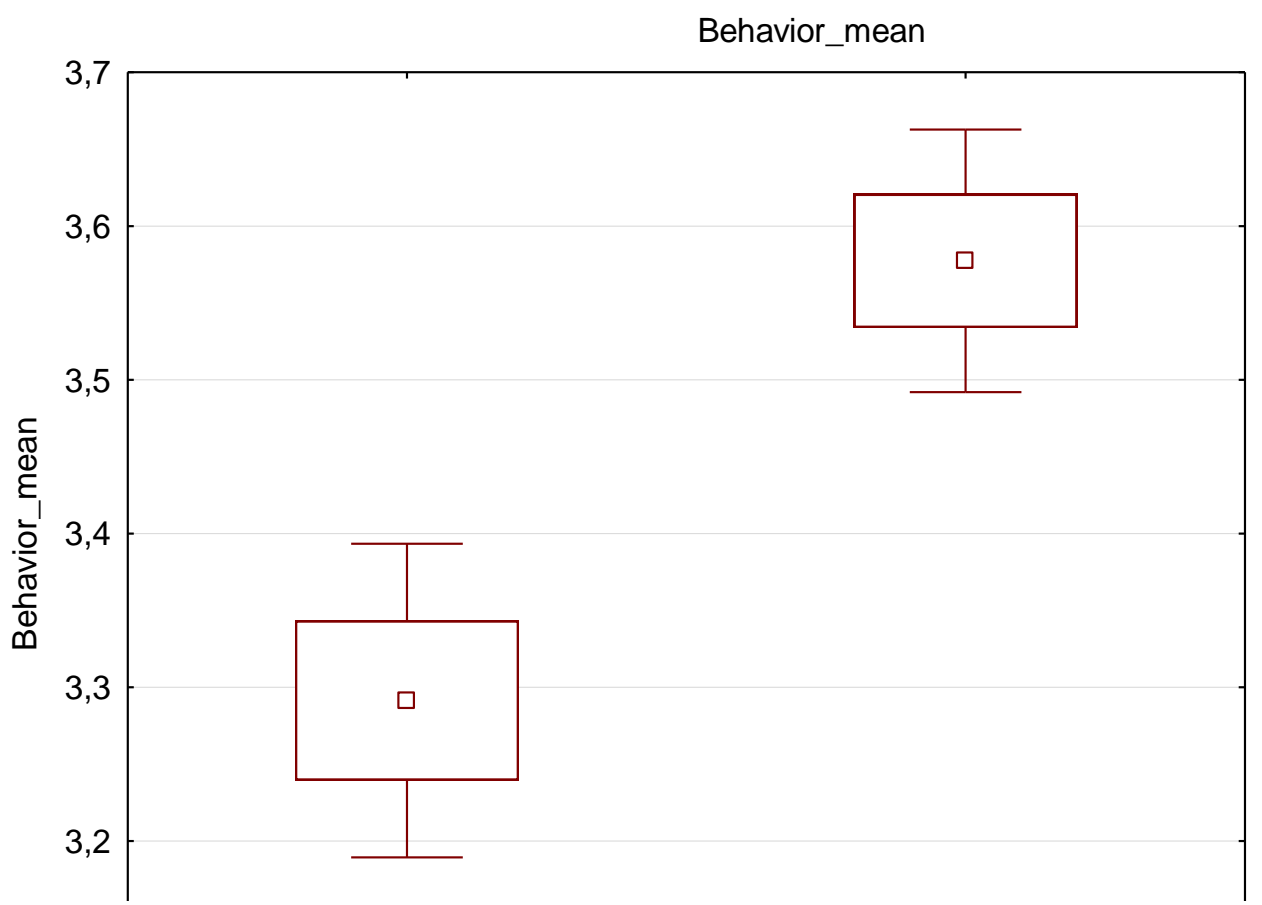

Figure 2 Relationship between declared environmental behaviour and gender

The connection of environmental literacy to age

First we used a single-factor analysis of variance (ANOVA) to find the relationship of individual scales to age. The knowledge scale had a significant correlation with age (see Figure $3, p=.002$ ). Based on the results of the Tukey HSD test, a statistically significant difference was identified between grades 6 and $8(p=.001)$ and grades 6 and $9(p=.030)$. Figure 3 shows a direct correlation between the age and the level of environmental knowledge, which increased from grade 6 to grade 8 , then slightly decreased. The situation described could be due, for example, to the inclusion and gradual discussion 
of the topics concerned from the 6th to the 8th grade, while in the 9th grade they may forget about them somewhat.

Current effect: $F(3,463)=4,9925, p=, 00204$

Decomposition of effective hypothesis

The vertical bars indicate the 0.95 confidence intervals

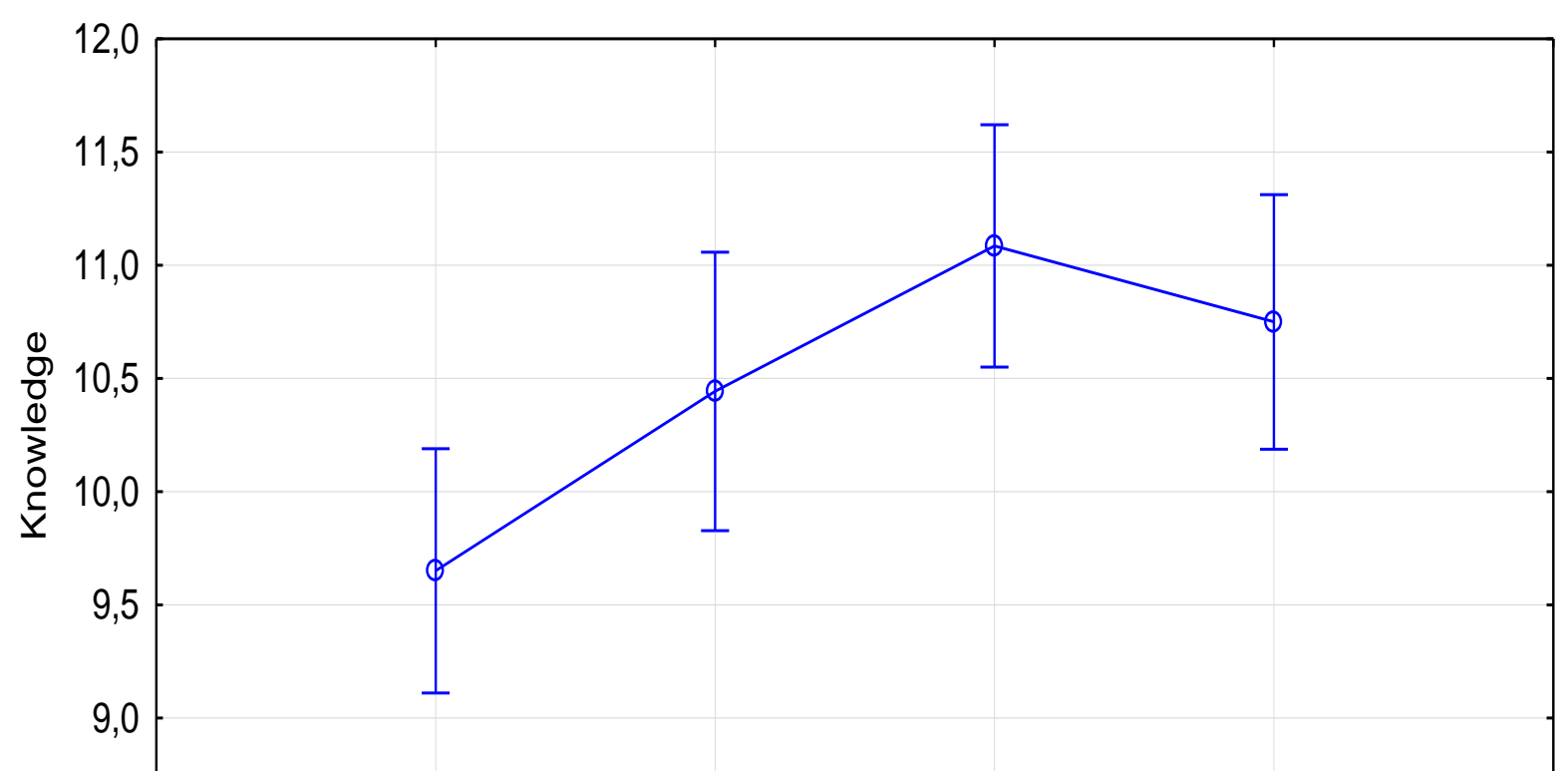

Figure 3 Relationship between environmental knowledge and school grade

For the other scales, ANOVA and the graph did not offer readily interpretable results, so we chose the Spearman correlation coefficient to look for possible connections. This proved to be statistically significant. The Spearman correlation coefficients between the scales of the tools in question and the age variable are always negative and almost identical, as shown in Table 5. In the higher school grades, the attitudes, sensitivity, and behaviour values drop significantly.

Table 5

Overview of Spearman's correlations between the scales of the tools and grade

\begin{tabular}{llll}
\hline & \multicolumn{3}{c}{ Scales of the tools } \\
\cline { 2 - 4 } Variable & Attitudes & Sensitivity & Behaviour \\
\hline grade & -.16 & -.16 & $\mathbf{- 1 5}$ \\
\hline
\end{tabular}

Note: All values are significant $(\mathrm{p}<.01)$.

\section{Relationship between environmental literacy and leisure activities}

The relationship between scales of the tools and leisure activities (outdoor activities, ICT, hobbies, sport) was also subjected to correlation analysis. A statistically significant relationship for leisure activities was identified in attitudes (except sport), sensitivity and behaviour. In the case of ICT, there was a negative trend, unlike for the other activities. The strongest correlation was outdoor activities with environmental sensitivity (see Table 6). 
Table 6

Overview of Spearman's correlations between scales of tools and leisure activities

\begin{tabular}{lllll}
\hline & \multicolumn{4}{c}{ Leisure activities } \\
\cline { 2 - 5 } Variable & Outdoor activities & ICT & Hobbies & Sport \\
\hline Knowledge & .07 & -.02 & .05 & -.05 \\
Attitudes & .22 & -.23 & .16 & .03 \\
Sensitivity & .45 & -.21 &. $\mathbf{3 2}$ & .28 \\
Behaviour & .31 & -.29 & .16 & .09 \\
\hline
\end{tabular}

Note: Values in bold are significant $(\mathrm{p}<.01)$.

The results of multiple regression shown in Table 7 show the dependence of the attitudes, sensitivity and behaviour variables on leisure activities. The values of the coefficient of determination $\mathrm{R}^{2}$ indicate that these leisure activities (outdoor activities, ICT, hobbies and sport) predict attitudes by $14 \%$, sensitivity by $30 \%$ and behaviour by $18 \%$. The strongest positive relationship, or rather the highest positive value of the regression coefficient was recorded for outdoor stays, for all three variables, unlike ICT, where negative dependence is apparent. For sensitivity, a significant correlation was identified for all four leisure activities.

Table 7

Results of regression analysis between scales of tools and leisure activities

\begin{tabular}{llllll}
\hline Variable & & Outdoor activities & ICT & Hobbies & Sport \\
\hline Attitudes & .14 & $.239^{* * *}$ & $-.218^{* * *}$ & $.131^{*}$ & -.092 \\
Sensitivity & .30 & $.368^{* * *}$ & $-.150^{* * *}$ & $.193^{* * *}$ & $.107^{*}$ \\
Behaviour & .18 & $.282^{* * *}$ & $-.244^{* * *}$ & .091 & -.028 \\
\hline
\end{tabular}

Note: $\mathrm{b}^{*}=$ regression coefficient; ${ }^{*} \mathrm{p}<.05 ;{ }^{* *} \mathrm{p}<.01 ; * * \mathrm{p}<.001$.

A multiple regression analysis performed between the variables attitudes, sensitivity and behaviour as explanatory variables, and leisure activities, gender, and age as explanatory variables, brought about some interesting results. The values of determination for the coefficient $R^{2}$ increased for all three dependent variables. The results in Tables 8 show that leisure activities in combination with gender explain the variability of the variable attitudes by $15 \%$, by $31 \%$ for sensitivity and by $19 \%$ for behaviour. The results in Tables 9 show that leisure activities in combination with grade explain the variability of the variable attitudes by $16 \%$, by $33 \%$ for sensitivity and by $20 \%$ for behaviour. A significant relationship between all four leisure activities and age was found for attitudes.

Table 8

Results of regression analysis between scales of tools and leisure activities, including gender

\begin{tabular}{lllllll}
\hline Variable & & Outdoor activities & ICT & Hobbies & Sport & Gender \\
\hline Attitudes & .15 & $.230^{* * *}$ & $-.211^{* * *}$ & $.112^{*}$ & -.075 & -.079 \\
Sensitivity & .31 & $.362^{* * *}$ & $-.145^{* * *}$ & $.181^{* * *}$ & $.118^{*}$ & -.049 \\
Behaviour & .19 & $.270^{* * *}$ & $-.235^{* * *}$ & .067 & -.006 & $-.103^{*}$ \\
\hline
\end{tabular}

Note: $\mathrm{b}^{*}=$ regression coefficient; ${ }^{*} \mathrm{p}<.05$; $^{* *} \mathrm{p}<.01$; $^{* *} \mathrm{p}<.001$; code 1 : girls, code 2 : boys.

Table 9

Results of regression analysis between scales of the tools and leisure activities, including grade

\begin{tabular}{lllllll}
\hline Variable & & Outdoor activities & ICT & Hobbies & Sport & Grade \\
\hline Attitudes & .16 & $.240^{* * *}$ & $-.215^{* * *}$ & $.136^{* *}$ & $-.110^{*}$ & $-.150^{* * *}$ \\
Sensitivity & .33 & $.369^{* * *}$ & $-.147^{* * *}$ & $.198^{* * *}$ & .088 & $-.166^{* * *}$ \\
Behaviour & .20 & $.283^{* * *}$ & $-.241^{* * *}$ & $.096^{*}$ & -.045 & $-.148^{* * *}$ \\
\hline
\end{tabular}

Note: $\mathrm{b}^{*}=$ regression coefficient; ${ }^{*} \mathrm{p}<.05 ;{ }^{* *} \mathrm{p}<.01 ;{ }^{* * *} \mathrm{p}<.001$. 


\section{Discussion}

The environmental literacy of ISCED 2 pupils was investigated by measuring their environmental knowledge, attitudes, sensitivity and behaviour. Knowledge was operationalized with test tasks, and attitudes and sensitivity with a questionnaire asking for their opinions; for behaviour, it was not about the actual behaviour of the pupils but rather what they stated.

A comparison of the observed reliability of the subscales of the author's tool with the reliability values of the original scales (MSELS) and tools (2-MEV) did not reveal any significant differences. For the Environmental Attitude scale, $\alpha=.78$ does not differ significantly from the original value (2-MEV) $\alpha=.83$ (Johnson \& Manoli, 2011), nor does it differ for the Environmental Sensitivity scale, $\alpha=.79$ (MSELS: $\alpha=.76$ ) (McBeth et al., 2008). A more significant difference was recorded for the Environmental Knowledge scale, $\alpha=.71$, where the original value was $\alpha=.79$ (McBeth et al., 2008). When testing this modified MSELS scale in the Czech environment in other research, a significantly lower value of $\alpha=.63$ was measured (Činčera, 2013).

The relationship between the dimensions of environmental literacy was identified through correlation analysis, with a statistically significant relationship manifested in particular between the affective and conative dimensions. Spearman's correlation coefficient was high: between attitudes and behaviour it was .65, and between sensitivity and behaviour it was .63. Knowledge correlated only with attitudes, where the value of the correlation coefficient was .30. Thus, people who hold a pro-environmental attitude and show a high level of sensitivity can also be expected to act in an environmentally responsible manner.

Several research studies have been devoted to the relationship between the various dimensions of environmental literacy. The generally rejected and traditional knowledge-attitude-behaviour theory (KAB) model (Ramsey \& Rickson, 1976), which is based on a narrow linear relationship between knowledge, attitudes and behaviour, is not widely supported in the literature (Bamberg \& Möser, 2007; Heimlich \& Ardoin, 2008; Hines, Hungerford, \& Tomera, 1987; Hungerford \& Volk, 1990; Marcinkowski, 1991). For example, Hungerford and Volk (1990) identified a statistically significant relationship between the affective and the conative dimensions, but the effect of the cognitive dimension has not been demonstrated.
The relationship between the environmental literacy of Czech pupils at ISCED level 2 and the variables (gender, grade and leisure activities) was identified as statistically significant. Outdoor activities predict especially the environmental sensitivity.

In the case of environmental attitudes, sensitivity and behaviour, there was a significant relationship with gender, with girls scoring higher in all three scales. The same findings with regard to the statistically significant relationship between the demographic variable gender and the affective dimension of environmental literacy were reported by, for example, Bílek and Schmutzerová (2010), Kubiatko (2014) and Kroufek, Janovec and Chytrý (2015). In contrast, Zelezny, Chua, and Aldrich (2000), Ogunbode and Arnold (2012), Ogunbode (2013) and Nastoulas et al. (2017) did not find that gender had an effect. Many studies show that women have a more attentive attitude towards the environment than men (e.g. Davidson \& Freudenberg, 1996; Godfrey, 2005; Leach, 2007; Tindall, Davies, \& Mauboules, 2003; Unger, 2008; Van Liere \& Dunlap, 1980; Zelezny \& Bailey, 2006).

The age variable proved to be a significant factor in all dimensions of environmental literacy. Environmental knowledge increases significantly with age, while attitudes, sensitivity and behaviour decline. Through the MSELS research tool, the older respondents in the National Environmental Literacy Project in the United States also showed a broader range of knowledge, while their attitudes 
and sensitivity were lower (McBeth \& Volk, 2010; McBeth et al., 2011). Similar discoveries regarding the negative correlation of attitudes with age were made for Greek students (Nastoulas et al., 2017). Bogner et al. (2015), who used the 2-MEV in their research, came to the same conclusions.

One of the key factors that may be responsible for this trend could be the change in respondents' interests and other personality development processes during adolescence.

The tested leisure activities (outdoor activities, ICT, hobbies and sport) positively correlate with attitudes, sensitivity and behaviour, but negatively with ICT. Outdoor activities proved to be the strongest predictor for attitudes, sensitivity and behaviour, especially in combination with gender or age. Geng, Xu, Ye, Zhou, and Zhou (2015), Pereira and Forster (2015) and Kroufek et al. (2016) also had findings consistent with the positive impact of regular outdoor activities on environmentally responsible behaviour. Outdoor education is thus an effective means of implementing environmental education (Činčera, 2015). Of the organizational forms of teaching, it would be appropriate to include regular fieldwork, inquiry-based teaching, excursions and various environmentally-oriented projects. School gardens also offer significant potential in this respect.

\section{$5 \quad$ Limitations of the study}

The limitation of the presented research is mainly the method of respondent selection, as the respondents were not randomly selected. The respondents were only from schools in the Ústí Region, which does not represent a typical region of the Czech Republic, and therefore the results cannot be generalized to the whole target group of lower-secondary pupils in the Czech Republic.

\section{Conclusion}

The text presents the partial results of the pilot research of the authorial analytical tool for the comprehensive measurement of environmental literacy of lower-secondary-school pupils in the Czech Republic, describing the connection of specific variables with individual dimensions: cognitive, affective and conative. From the results of the analysis of the psychometric properties of the tool, which were published separately and of which only the values of reliability of the scales are given in this paper, the tool can be evaluated as applicable for the purpose. The value of the Cronbach $\alpha$ coefficient ranged from .71-.79. These values can be considered sufficient (Tavakol \& Denick, 2011). The individual dimensions of environmental literacy correlate positively with each other. The cognitive dimension has a negligible dependence, as opposed to the reasonably close relationship between the affective and conative dimensions. In the case of gender, there was a significant relationship between attitudes, sensitivity and behaviour, with girls always achieving higher values. Regarding age, the link between this variable and all dimensions proved to be statistically significant. A direct proportion was identified between age and knowledge, as opposed to attitudes, sensitivity, and behaviour, whose values declined with age. Leisure activities in combination with gender or age, especially outdoor activities, can be considered crucial factors in predicting the variables of environmental attitudes, sensitivity and behaviour. Many other studies have also demonstrated the positive impact of regular outdoor activities on environmental literacy.

While the results of the pilot study cannot be generalized due to the limited selection available, they provide interesting findings, especially in the area of leisure activities and the impact of gender on the environmental literacy of lower-secondary-school pupils. When developing educational programmes within environmental education, developers should primarily include, alongside the gender aspect, activities undertaken in the outdoors. 
Svobodová / Environmental literacy of pupils and its investigation in the Czech Republic 100

This article was created with full financial support from the grant project GA UK No. 50119. The text is published with the support of the Czech Association of Educational Research and the Council of Scientific Societies. It was presented at the ČAPV 2019 conference.

\section{Reference}

AERA, APA \& NCME. (2014). Standards for educational and psychological testing. Washington, D.C.: American Educational Research Association.

Andrews, K. E., Tressler, K. D., \& Mintzes, J. J. (2008). Assessing environmental understanding: an application of the concept mapping strategy. Environmental Education Research, 14(5), 519536.

Ballard, M., \& Pandya, M. (1990). Essential learnings in environmental education. Troy: NAAEE.

Bamberg, S., \& Möser, G. (2007). Twenty years after Hines, Hungerford, and Tomera: A new metaanalysis of psycho-social determinants of pro-environmental behaviour. Journal of Environmental Psychology, 27(1), 14-25. https://doi.org/10.1016/j.jenvp.2006.12.002

Bílek, M., \& Schmutzerová, L. (2010). Jak hodnotili čeští patnáctiletí žáci základních škol a studenti víceletých gymnázií environmentální problémy. Envigogika, 5(2), 1-13. https://doi.org/10.14712/18023061.54

Blažek, R., \& Příhodova, S. (2016). Mezinárodní šetřeni PISA 2015. Národní zpráva. Přírodovědná gramotnost. Praha: ČŠl. Dostupné z https://www.csicr.cz/Csicr/media/Prilohy/PDF_el._publikace/Mezin\%C3\%A1rodn\%C3\%AD\%20 \%C5\%A1et\%C5\%99en\%C3\%AD/NZ_PISA_2015.pdf

Bogner, F. X., Johnson, B., Buxner, S., \& Felix, L. (2015). The 2-MEV model: Constancy of adolescent environmental values within an 8 year time frame. Internatio-nal Journal of Science Education, 37(12), 1938-1952. https://doi.org/10.1080/09500693.2015.1058988

Bragg, R., Wood, C, Barton, J., \& Pretty, J. (2013). Measuring connection to nature in children aged 812: A robust methodology for the RSPB. Essex: University of Essex. Retrieved from https://www.rspb.org.uk/globalassets/downloads/documents/positions/education/measuring -connection-to-nature-in-children-aged-8---12---methodology.pdf

Broukalová, L., Broukal, V., Činčera, J., Daniš, P., Kažmierski, T., Kulich, J., Lupač, M., Medek, M., \& Novák, M. (2012). Cíle a indikátory pro environmentální vzdělávání, výchovu a osvětu v České republice. Praha: MŽP ČR.

Činčera, J. (2007). Environmentální výchova: Od cílů k prostředkům. Brno: Paido.

Činčera, J. (2009). Analýza prưřezového tématu Environmentální výchova v Rámcovém vzdělávacím programu pro základní vzdělávání. Envigogika, 4(1), 1-27. Dostupné z https://doi.org/10.14712/18023061.33

Činčera, J. (2011). Doporučené očekávané výstupy pro environmentální výchovu. Envigogika, 6(2), 117. https://doi.org/10.14712/18023061.59

Činčera, J. (2013). Metodika pro hodnocení environmentální výchovy pro starší školní věk a střední školy. Envigogika, 8(5), 1-63. https://doi.org/10.14712/18023061.414

Činčera, J. (2015). Učení se ve skutečném světě: Kritická analýza. Envigogika, 10(3), 1-12. https://doi.org/10.14712/18023061.473

Činčera, J. (2017). Environmentální výchova jako průřezové téma: Podkladová studie. Praha: NúV.

Činčera, J., \& Johnson, B. (2013). Earthkeepers in the Czech Republic: Experience from the implementation process of an earth education programme. Envigogika, 8(4), 1-14. https://doi.org/10.14712/18023061.397 
Svobodová / Environmental literacy of pupils and its investigation in the Czech Republic

ČŠI. (2017). Výběrové zjištování výsledků žáků na úrovni 5. a 9. ročniků základních škol ve školním roce 2016/2017 - závěrečná zpráva. Dostupné z https://www.csicr.cz/getattachment/17f8e265b04f-4459-a106-3aecbf735ca0/Vyberove-zjistovani-vysledku-zaku-na-urovni-5-a-9-rocniku-ZSzaverecna-zprava.pdf

Daniš, P. (2013). Nové vymezení environmentální gramotnosti a návrh na její mezinárodní testování v PISA 2015. Envigogika, 8(3), 1-16. https://doi.org/10.14712/18023061.385

Davidson, D. J., \& Freudenburg, W. R. (1996). Gender and environmental risk concerns: A review and analysis of available research. Environment and Behavior, 28(3), 302-339.

Disinger, J. F. (2005). Environmental Education's Definitional Problem. In H. R. Hungerford, W. Bluhm, T. L. Volk, \& J. M.Ramsey, Essential Readings in Environmental Education (pp. 17-32). Champaign: Stipes.

Erdogan, M., Akbunar, S., Asik, U. O., Kaplan, H., \& Kayir, C. G. (2012). The effects of demographic variables on students' responsible environmental behaviors. Pocedia - Social and Behavioral Sciences, 46, 3244-3248. https://doi.org/10.1016/j.sbspro.2012.06.044

Geng, L., Xu, J., Ye, L., Zhou, W., \& Zhou, K. (2015). Connections with Nature and Environmental Behaviors. PloS One, 10(5), e0127247. https://doi.org/10.1371/journal.pone.0127247

Godfrey, P. (2005). Diane Wilson vs. Union Carbide: Ecofeminism and the elitist charge of "essentialism." Capitalism Nature Socialism, 16(4), 37-56.

Grúňová, M., Sané, M., Čincera, J., Kroufek, R., \& Hejcmanová, P. (2018). Reliability of the new environmental paradigm for analysing the environmental attitudes of Senegalese pupils in the context of conservation education projects. Environmental Education Research, 25(2), 211-221. https://doi.org/10.1080/13504622.2018.1428942

Gul, S., \& Yesilyurt, S. (2011). A study on primary and secondary school students' misconceptions about Greenhouse Effect (Erzurum Sampling). International Electronic Journal of Environmenal Education, 1(3), 193-202.

Heimlich, J. E., \& Ardoin, N. M. (2008). Understanding behavior to understand behavior change: a literature review. Environmental Education Research, 14(3), 215-237. https://doi.org/10.1080/13504620802148881

Hines, J. M., Hungerford, H. R., \& Tomera, A. N. (1987). Analysis and synthesis of research and responsible environmental behavior: A meta analysis. Journal of Environmental Education, 18(2), 1-8. https://doi.org/10.1080/00958964.1987.9943482

Hollweg, K. S., Taylor, J. R., Bybee, R. W., Marcinkowski, T. J., McBeth, W. C., \& Zoido, P. (2011). Developing a framevork for assessing environmental literacy. Washington, D.C.: North American Association for Environmental Education.

Hungerford, H. R. \& Volk, T. L. (1990). Changing Learner Behavior Through Environmental Education. The Journal of Environmental Education, 21(3), 8-21.

Hungerford, H. R., Peyton, B. R., \& Wilke, R. J. (1980). Goals for curriculum development in environmental education. The Journal of Environmental Education, 11(3), 42-47.

Hungerford, H. R., Volk, T., Wilke, R., Champeau, R., Marcikowski, T., May, T., Bluhm, W. \& McKeownIce, R. (1994). Environmental literacy framework. Environmental education literacy consorcium. Carbondale, IL: Southern Illinois University.

Johnson, B., \& Manoli, C. C. (2008). Using Bogner and Wiseman's model of ecological values to measure the impact of an earth education programme on children's environmental perceptions. Environmental Education Research, 14(2), 115-127. https://doi.org/10.1080/13504620801951673 
Svobodová / Environmental literacy of pupils and its investigation in the Czech Republic

Johnson, B., \& Manoli, C. C. (2011). The 2-MEV scale in the US: A measure of children's environmental attitudes based on the theory of ecological attitude. Journal of Environmental Education, 42(2), 84-97. https://doi.org/10.1080/00958964.2010.503716

Kormos, C. \& Gifford, R. (2014). The validity of self-report measures of proenvironmental behavior: A meta-analytic review. Journal of Environmental Psychology, 40, 359-371. https://doi.org/10.1016/j.jenvp.2014.09.003

Kroufek, R., Chytrý, V., Janovec, J., \& Brtnová Čepičková, I. (2016). Effect of leisure activities on responsible environmental behaviour of pupils of primary school. Proceedings of the ICERI, 7451-7456. https://doi.org/10.21125/iceri.2016.0703

Kroufek, R., Janovec, J., \& Chytrý, V. (2015). Pre-service primary teachers and their attitudes towards nature. In O. Fleischmann, R. Seebauer, H. Zoglowek, \& M. Aleksandrovich (Eds.), The teaching profession: New challneges - New identities (pp.129-137). Wien: Lit Verlag GmbH \& Co.

KÚ Ústeckého kraje. (2011). Problémová analýza Ústeckého kraje. Dostupné z https://www.krustecky.cz/assets/File.ashx?id_org=450018\&id_dokumenty=1666198

Kubiatko, M. (2014). The environmental literacy of lower secondary school pupils, high school and college students. Journal of Environmental Science and Engineering Technology, 2(1), 2-8. https://doi.org/10.12974/2311-8741.2014.02.01.1

Leach, M. (2007). Earth mother myths and other ecofeminist fables: How a strategic notion rose and fell. Development and Change, 38(1), 67-85.

Liefländer, A. K., \& Bogner, F. X. (2014). The effects of children's age and sex on acquiring proenvironmental attitudes through environmental education. The Journal of Environmental Education, 45(2), 105-117. https://doi.org/10.1080/00958964.2013.875511

Lozzi, L., Laveaut, D., \& Marcinkowski, T. (1990). Assessment of learning outcomes in environmental education. Paris: UNESCO.

Marcinkowski, T. (1991). The relationship between environmental literacy and responsible environmental behavior in environmental education. In N. Maldague (Ed.), Methods and techniques for evaluating environmental education. Paris: UNESCO.

Marcinkowski, T. (2005). Predictors of responsible environemental behavior. A review of three disertation studies. In H. R. Hungerford, W. Bluhm, T. L. Volk, \& J. M. Ramsey (Eds.), Essential readings in environmental education (pp. 265-294). Champaign: Stipes.

McBeth, W., \& Volk, T. L. (2010). The National Environmental Literacy Project: A baseline study of middle grade students in the United States. The Journal of Environmental Education, 41(1), 5567.

McBeth, W., Hungerford, H., Marcinkowski, T., Volk, T. L., \& Cifranick, K. (2011). The National Environmental Literacy Assessment, phase two: Measuring the effectiveness of North American Environmental Education Programs with respect to the parameters of environmental literacy. Retrieved from https://www.noaa.gov/sites/default/files/atoms/files/NELA_Phase_Two_Report_020711.pdf

McBeth, W., Hungerford, H., Marcinkowski, T., Volk, T. L., \& Meyers, R. (2008). National Environmental Literacy Assessment Project: Year 1, National baseline study of middle grades students final research report. Retrieved from https://www.noaa.gov/sites/default/files/atoms/files/Final_NELA_minus_MSELS_8-1208_0.pdf 
Svobodová / Environmental literacy of pupils and its investigation in the Czech Republic

McBride, B. B., Brewer, C. A., Berkowitz, A. R., \& Borrrie, W. T. (2013). Environmental literacy, ecological literacy, ecoliteracy: What do we mean and how did we get here? Ecosphere, 4(5), 120. https://doi.org/10.1890/ES13-00075.1

MŠMT. (2017). Rámcový vzdělávací program pro základní vzdělávání. Praha: MŠMT.

NAAEE. (2010). Excellence in environmental education: Guidelines for Learning (K-12). Washington, D.C.: NAAEE.

NAAEE. (2019). K-12 Environmental education: Guidelines for excellence executive summary. Washington: NAAEE.

Nastoulas, I., Marini, K., \& Skanavis, C. (2017). Middle School Students Environmental Literacy Assessment in Thessaloniki, Greece. Proceedings of the Health and Environment Conference, 198-209. Dubai: Hamdan Bin Mohammed Smart University.

Ogunbode, Ch. A., \& Arnold, K. (2012). A study of environmental awareness and attitudes in Ibadan, Nigeria. Human and Ecological Risk Assessment: An International Journal, 18(3), 669-684.

Ogunbode, Ch. A. (2013). The NEP Scale: Measuring ecological attitudes/worldviews in an African context. Environment, Development and Sustainability, 15(6), 1477-1494.

Osbaldiston, R., \& Schott, J. P. (2012). Environmental sustainability and behavioral science: MetaAnalysis of proenvironmental behavior experiments. Environment \& Behavior, 44(2), 257-299. https://doi.org/10.1177/0013916511402673

Pereira, M., \& Forster, P. (2015). The relationship between connectedness to nature, environmental values and pro-environmental behaviours. Reinvention: and International Journal of Undergraduate Research, 8(2). Retrieved from https://warwick.ac.uk/fac/cross_fac/iatl/reinvention/archive/volume8issue2/pereira/

Ramsey, J. M., Hungerford, H. R., \& Volk, T. L. (1992). Environmental education in the K-12 curriculum: Finding a niche. The Journal of Environmental Education, 23(2), 35-45. https://doi.org/10.1080/00958964.1992.9942794

Roth, C. E. (1992). Environmental literacy: Its roots, evolution, and directions in the 1990s. Columbus: ERIC Clearingouse for Science, Mathematics and Environmental Education.

Sanera, M. (1998). Environmental education: promise and perfomance. Canadian Journal of Environmental Education, 3, 9-26.

Schovajsová, J. (2010). Současný stav environmentální výchovy na základních školách - vybrané aspekty environmentální gramotnosti dětí mladšího školního věku (Disertační práce). Olomouc: Univerzita Palackého v Olomouci.

Statsoft. (2018). Statistica 12. Dostupné z http://www.statsoft.cz/

Stevenson, K. T., Carrier, S. J., \& Peterson, M. N. (2014). Evaluating strategies for inclusion of environmental literacy in the elementary school classroom. Electronic Journal of Science Education, 18(8), 1-17.

Stevenson, K. T., Peterson, M. N., Bondell, H. D., Mertig, A. G., \& Moore, S. E. (2013). Environmental, institutional, and demographic predictors of environmental literacy among middle school children. PLOS ONE, 8(3). https://doi.org/10.1371/journal.pone.0059519

Svobodová, S. (2017). Vliv vybraných proměnných na environmentální gramotnost žáků 2. stupně základní školy. Envigogika, 12(1), 1-22. https://doi.org/10.14712/18023061.539

Svobodová, S. (2018a). Konativní dimenze environmentální gramotnosti českých a slovenských žáků 2. stupně Zš. Envigogika, 13(2), 1-12. https://doi.org/10.14712/18023061.578 
Svobodová / Environmental literacy of pupils and its investigation in the Czech Republic

Svobodová, S. (2018b). Environmentální gramotnost žáků 2. stupně základní školy v České republiceaplikovatelnost zahraničních výzkumných nástrojü. Proceedings of the XXVI. conference of the Czech Association of Educational Research Transdisciplinarity in Educational Sciences, ČAPV and FHS TBU in Zlín, 133-134.

Svobodová, S., \& Chvál, M. (2019). The pilot verification of the Authoring Research Tool for the comprehensive measurement of environmental literacy of ISCED level 2 pupils in the Czech Republic. Proceedings of the 13th International Technology, Education and Development Conference, 1947-1958. https://doi.org/10.21125/inted.2019.0553

Svobodová, S., \& Kroufek, R. (2018). Možnosti využití škály MSELS pro testování environmentální gramotnosti na základních školách v České republice. Scientia in educatione, 9(2), 80-101. https://doi.org/10.14712/18047106.1210

Tavakol, M., \& Dennick, R. (2011). Making sense of Cronbach's alpha. International Journal of Medical Education, 2011(2), 53-55. https://doi.org/10.5116/ijme.4dfb.8dfd

Tindall, D. B., Davies, S., \& Mauboules, C. (2003). Activism and conservation behavior in an environmental movement: The contradictory effects of gender. Society and Natural Resources, 16(10), 909-932.

UNESCO. (1977). Intergovernmental Conference on Environmental Education - Final report. Retrieved from https://unesdoc.unesco.org/ark:/48223/pf0000032763.

Unger, N. C. (2008). The role of gender in environmental justice. Environmental Justice, 1(3), 115-120.

Vacínová, M., \& Matějček, T. (2013). Intergenerational differences in personal relationship to nature. Envigogika, 8(2), 1-19. https://doi.org/10.14712/18023061.384

Van Liere, K. D., \& Dunlap, R. E. (1980). The social bases of environmental concern: A review of hypotheses, explanations and empirical evidence. Public Opinion Quarterly, 44(2), 181-197.

Wilke, R. (Ed.). (1995). Environmental Education Literacy/Needs Assessment Project: Assessing environmental literacy of students and environmental education needs of teachers. Stevens Point: University of Wisconsin.

Zelezny, L., \& Bailey, M. (2006). A call for women to lead a different environmental movement. Organization\&Environment, 19(1), 103-109.

Zelezny, L. C., Chua, P. P., \& Aldrich, C. (2000). New ways of thinking about environmentalism: Elaborating on gender differences in environmentalism. Journal of Social Issues, 56(3), 443-457.

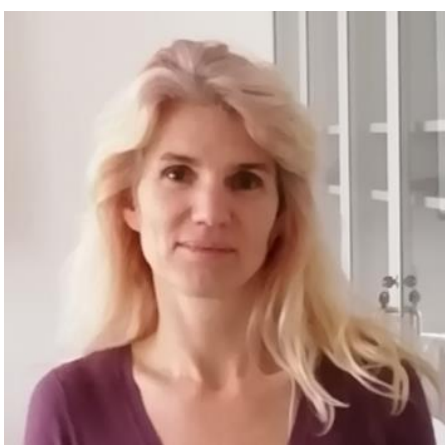

Silvie Svobodová is a PhD student at the Faculty of Education, Charles University, where she study in the field of Biology Education at the Department of Biology and Environmental Studies. In her dissertation thesis she focuses on environmental literacy testing of pupils ISCED 2 in the Czech Republic, Slovakia, Poland and Germany. Her main task is to compile and verify the author's analytical tool. Furthermore, to create a compact real idea of environmental literacy of pupils ISCED 2, especially in the Czech Republic and Slovakia. In her professional life she also actively participate in environmental education. 


\section{Appendix 1}

\section{Questionnaire}

Dear pupil!

By carefully filling out this anonymous questionnaire, you can help me to find out what pupils of your age know about nature and what they think about protecting nature and the environment.

The questionnaire contains a few parts. Read responsibly the instructions for each part. For each item, choose just one answer that best describes your opinion, and circle the letter.

Thank you for your answers.

Silvie Svobodová (Charles University of Prague)

\section{A. Demographic data}

1. Age
a) twelve
b) thirteen
c) fourteen
d) fifteen and older

2. Class/Form
a) Class 6
b) Class 7
c) Class 8
d) Class 9

3. Gender:
a) boy
b) girl

4. You pass your free time:

staying in nature
a) usually
b) very often
c) often
d) sometimes
e) never

staying on ICT (PC, mobile phone, tablet, etc.)
a) usually
b) very often
c) often
d) sometimes
e) never

regular attendance at some hobby/interest club/lesson (art, dance lessons, etc.)
a) usually
b) very often
c) often
d) sometimes
e) never

playing sports
a) usually
b) very often
c) often
d) sometimes
e) never

\section{B. Knowledge of nature}

Circle only one, the best answer for each question.

5. Flowers with colorful petals and a sweet smell would most likely be pollinated by:
a) rain
b) wind
c) birds
d) insects

6. A small bird eats a butterfly that has been eating some nectar from a flower. Then the bird is eaten by a hawk. This is an example of:
a) mutualism
b) a food chain
c) parasitism (parasitic behaviour)
d) survival of the fittest 
7. Which of the following is a predator - prey relationship?
a) a flea and a dog
b) a seven-spot ladybird and an aphid
c) a caterpillar and a leaf
d) a deer and a grasshopper on a blade of grass

8. A fox dies. This creates a problem for:
a) a rabbit living in its territory (an area where the fox lives)
b) another fox whose territory is nearby
c) other predators living in its territory
d) fleas that were drinking the fox's blood

9. Termites eat only wood; however, they cannot digest it. Tiny organisms that live in termites' stomachs and intestines digest the wood. The relationship the tiny organisms and the termites have is:
a) helpful to one and has no effect on the other
b) helpful to one and harmful to the other
c) helpful to both of them
d) helpful to neither of them

10. A cat and a snake are hunting the same mouse. What is the relationship between the cat and the snake?
a) One is using the other but not harming it
b) they are competing with each other
c) they are helping each other
d) one is trying to eat the other one

11. If there were no decomposers on Earth, what would happen?
a) many human diseases would disappear
b) living organisms would have more food
c) little would change
d) dead parts of plants and dead animals wouldn't become part of the soil

12. A grassland turns into a desert. What will most likely happen to the animals that live in the grassland?
a) their biodiversity and quantity will decrease
b) they will have more babies to survive
c) herbivores will adapt to another food
d) many of them will adapt to new conditions in the following generation

13. Some people started a program in a national forest to protect deer (e.g. stags, fallow deer). They started killing wolves. Ten years later there were no wolves in the forest. For a few years after the wolves were gone there were more deer than there had ever been. Then suddenly there were almost no deer. The people who wanted to protect the deer didn't know that:
a) deer only live to be a few years old
b) fires would kill so many deer
c) other animals would eat so much of the deer's food
d) the deer would eat all of the food and many would starve 
14. The original source of energy for almost all living things is:
a) the soil
b) water
c) the sun
d) plants

15. A dead bird is decomposing. What happens to the energy that was stored in the bird's body?
a) nothing happens to it. Once the bird is dead, the energy is lost
b) the bird used up its energy when it was alive
c) it is destroyed by solar radiation
d) it will pass through the organisms that decompose the dead body

16. A rabbit eats some corn. The energy from the corn goes into the rabbit. The next day a fox eats the rabbit. The fox gets very little of the energy that was in the corn. Why?
a) a fox cannot digest corn
b) the rabbit had already digested the corn
c) corn doesn't have much energy
d) most of the corn's energy was used by the rabbit

17. Most of the oxygen in the atmosphere comes from:
a) water
b) green plants
c) the soil
d) fungi

18. Which of the following would give humans the most food energy from 1,000 pounds of plants?
a) feed the plants to insects, feed the insects to fish, and then humans eat the fish
b) humans eat the plants
c) feed the plants to cattle, then humans eat the cattle
d) feed the plants to fish, then humans eat the fish

19. After living things die, they decompose. As a result of this process, nutrients are:
a) released back into the environment to be recycled
b) destroyed by the bacteria of decay
c) changed from nutrients to oxygen and water vapor
d) evaporated due to the heat produced during decomposition

20. Which of the following is a part of the water cycle?
a) erosion
b) ocean tides
c) evaporation
d) decomposition

21. A pollutant gets into an ecosystem and kills large numbers of insects. How might this affect the ecosystem?
a) plants are not damaged so it doesn't affect the ecosystem.
b) it damages part of the ecosystem so it may affect the whole ecosystem.
c) it kills only insects so the other animals in the ecosystem stay healthy.
d) most animals eat plants so it doesn't affect the ecosystem much. 


\section{What you think of nature and the environment}

The following items contain several statements. Please read the text carefully.

For each item, choose just one answer that best describes your opinion.

22. If I ever have extra money, I will give some to help protect nature.
a) strongly agree
b) slightly agree
c) neutral or undecided
d) slightly disagree
e) strongly disagree

23. To save energy in the winter, I make sure the heat in my room is not on too high.
a) strongly agree
b) slightly agree
c) neutral or undecided
d) slightly disagree
e) strongly disagree

24. I would like to sit by a pond and watch dragonflies.
a) strongly agree
b) slightly agree
c) neutral or undecided
d) slightly disagree
e) strongly disagree

25. People have the right to change the environment (nature).
a) strongly agree
b) slightly agree
c) neutral or undecided
d) slightly disagree
e) strongly disagree

26. Building new roads is so important that trees should be cut down.
a) strongly agree
b) slightly agree
c) neutral or undecided
d) slightly disagree
e) strongly disagree

27. I would help raise money to protect nature.
a) strongly agree
b) slightly agree
c) neutral or undecided
d) slightly disagree
e) strongly disagree 
28. I always turn off the light when I do not need it anymore.
a) strongly agree
b) slightly agree
c) neutral or undecided
d) slightly disagree
e) strongly disagree

29. I like to go on trips to places like forests, away from cities.
a) strongly agree
b) slightly agree
c) neutral or undecided
d) slightly disagree
e) strongly disagree

30. I like a grass lawn more than a place where flowers grow on their own.
a) strongly agree
b) slightly agree
c) neutral or undecided
d) slightly disagree
e) strongly disagree

31. Because mosquitoes live in swamps, we should drain the swamps and use the land for farming.
a) strongly agree
b) slightly agree
c) neutral or undecided
d) slightly disagree
e) strongly disagree

32. I try to tell others that nature is important.

a) strongly agree b) slightly agree c) neutral or undecided d) slightly disagree e) strongly disagree

33. I try to save water by taking shorter showers or by turning off the water when I brush my teeth.
a) strongly agree
b) slightly agree
c) neutral or undecided
d) slightly disagree
e) strongly disagree

34. I like the quiet of nature.
a) strongly agree
b) slightly agree
c) neutral or undecided
d) slightly disagree
e) strongly disagree 
35. To feed people, nature must be cleared to grow food.
a) strongly agree
b) slightly agree
c) neutral or undecided
d) slightly disagree
e) strongly disagree

36. People are supposed to rule over the rest of nature.
a) strongly agree
b) slightly agree
c) neutral or undecided
d) slightly disagree
e) strongly disagree

37. Weeds should be killed because they take up space from plants we need.
a) strongly agree
b) slightly agree
c) neutral or undecided
d) slightly disagree
e) strongly disagree

\section{Your nature and environmental sensitivity}

We are going to ask you a few questions about the degree of your nature and environmental sensitivity, which means the feelings you experience in relation to nature and the environment.

For each question, circle just one answer that best describes your feelings.

38. Please give your best estimate of the extent to which you are environmentally sensitive.
a) to a great extent
b) to a large extent
c) to a moderate extent
d) to a small extent
e) to no extent

39. Please give your best estimate of the extent to which your family is environmentally sensitive.
a) to a great extent
b) to a large extent
c) to a moderate extent
d) to a small extent
e) to no extent

40. To what extent do you take part in family vacations or outings in the outdoors?
a) to a great extent
b) to a large extent
c) to a moderate extent
d) to a small extent
e) to no extent 
41. To what extent do you take part in activities such as going for walks, hiking, bicycling, canoeing, or kayaking?
a) to a great extent
b) to a large extent
c) to a moderate extent
d) to a small extent
e) to no extent

42. To what extent do you take part in bird-watching or nature photography?
a) to a great extent
b) to a large extent
c) to a moderate extent
d) to a small extent
e) to no extent

43. To what extent do you go camping with youth groups and organizations (e.g. sports clubs, Scouts, hobby clubs, etc.)?
a) to a great extent
b) to a large extent
c) to a moderate extent
d) to a small extent
e) to no extent

44. To what extent do you spend time in the out-of-doors alone - not as part of a class or youth group?
a) to a great extent
b) to a large extent
c) to a moderate extent
d) to a small extent
e) to no extent

45. To what extent do you enjoy reading books or magazines about nature and the environment?
a) to a great extent
b) to a large extent
c) to a moderate extent
d) to a small extent
e) to no extent

46. To what extent do you enjoy watching television shows, videos, CDs, or DVDs about nature and
a) to a great extent
b) to a large extent
c) to a moderate extent
d) to a small extent
e) to no extent

47. To what extent do you have a teacher or youth leader who is a role model for environmental sensitivity?
a) to a great extent
b) to a large extent 

c) to a moderate extent
d) to a small extent
e) to no extent

\section{E. What you personally do for nature and the environment}

For each question, circle just one answer that best descibes what you do or would do for nature and the environment.

48. If I had the opportunity, I would spend the night in the wilderness, meaning in the open air.
a) strongly agree
b) slightly agree
c) neutral
d) slightly disagree
e) strongly disagree

49. If I have the opportunity, I like going into nature.
a) strongly agree
b) slightly agree
c) neutral
d) slightly disagree
e) strongly disagree

50. If I have the opportunity, I like reading any publication or information source about the environment.
a) strongly agree
b) slightly agree
c) neutral
d) slightly disagree
e) strongly disagree

51. I would defend any mistreated animal.
a) strongly agree
b) slightly agree
c) neutral
d) slightly disagree
e) strongly disagree

52. I am not interested in air pollution problems.
a) strongly agree
b) slightly agree
c) neutral
d) slightly disagree
e) strongly disagree

53. If I had the opportunity, I would voluntarily take part in nature protection.
a) strongly agree
b) slightly agree
c) neutral 

d) slightly disagree
e) strongly disagree

54. If I had the opportunity, I would change my behaviour because of worries about the environment.
a) strongly agree
b) slightly agree
c) neutral
d) slightly disagree
e) strongly disagree

55. I would prefer a school trip to the wilderness to a school trip to a funfair.
a) strongly agree
b) slightly agree
c) neutral
d) slightly disagree
e) strongly disagree

56. I also ask other people what I can do to reduce nature pollution.
a) strongly agree
b) slightly agree
c) neutral
d) slightly disagree
e) strongly disagree

57. I sort the waste at home or at school.
a) strongly agree
b) slightly agree
c) neutral
d) slightly disagree
e) strongly disagree

\section{F. How you feel about nature and the environment}

Circle just one answer that best describes the degree of your agreement.

58. I love nature and the environment.
a) strongly agree
b) slightly agree
c) neutral
d) slightly disagree
e) strongly disagree

Now you have completed the questionnaire and can put your pen down.

Thanks for your participation! 